\title{
Growth performance and carcass characteristics of lambs fed halophytes as a partial or whole replacement of berseem hay
}

\author{
M.H. Ahmed ${ }^{\text {a }}$, A.Z.M. Salem ${ }^{\text {b,*, H.S. Zeweil }}{ }^{\mathrm{a}}$, X.Z. Sun ${ }^{\mathrm{c}}$, A.E. Kholif ${ }^{\mathrm{d}}$, \\ M.M.Y. Elghandour ${ }^{\mathrm{b}}$, M.S.I. Bahar ${ }^{\mathrm{a}}$ \\ a Animal and Fish Production Department, Faculty of Agriculture (Saba Basha), Alexandria University, Egypt \\ b Facultad de Medicina Veterinaria y Zootecnia, Universidad Autónoma del Estado de México, Estado de México, Mexico \\ c Grasslands Research Centre, AgResearch Limited, Private Bag 11008, Palmerston North, New Zealand \\ d Dairy Science Department, National Research Centre, 33 Bohouth St., Dokki, Giza, Egypt
}

\section{A R T I C L E I N F O}

\section{Article history:}

Received 1 November 2014

Received in revised form 3 May 2015

Accepted 6 May 2015

Available online 14 May 2015

\section{Keywords:}

Carcass

Growth performance

Halophyte

Lamb

\begin{abstract}
A B S T R A C T
The aim of this study was to evaluate partial or whole substitution of berseem hay with Atriplex nummularia (AT) and/or Acacia saligna (AC) in the diet of Barki lambs. Thirty-six male lambs (body weight $26.5 \pm 1.1 \mathrm{~kg}$ and age $13 \pm 1.1$ months) were divided into four groups and fed: (1) the control diet (70\% concentrate mixture and 30\% berseem hay), (2) AT (AT15 diet) or (3) AC (AC15 diet) replaced $50 \%$ of berseem hay in the diet, or (4) AT and $A C$ at a ratio of $1: 1$ to replace $100 \%$ of berseem hay (TC30 diet), respectively. Lamb growth performance, rumen fermentation, blood chemistry, carcass characteristics and intestine histological properties were investigated. Dry matter intake, daily weight gain and feed conversion were measured every two weeks (period) for 10 weeks. Interactions were observed $(P<0.05)$ between period $\times$ diet for these measurements and period affected $(P<0.05)$ daily weight gain and feed conversion. Lambs in the AT15 and AC15 groups had increased $(P<0.05)$ dry matter intake (g/lamb/day), water consumption ( $\mathrm{L} / \mathrm{lamb} /$ day), daily weight gain ( $\mathrm{g} / \mathrm{lamb} /$ day) and feed conversion (feed intake/body weight gain) during the last 2, 6, 2 and 8-10 weeks, respectively. The treatments AT15, AC15 and TC30 had decreased concentrations $(P<0.01)$ of ruminal volatile fatty acids, but did not affect ruminal ammonia$\mathrm{N}$ concentrations. Lambs fed the experimental diets had lower $(P<0.05)$ concentrations of blood cholesterol, low density lipoproteins and glucose and higher $(P<0.05)$ concentrations of serum urea. The treatment AT15 had increased $(P<0.05)$ gut fill, pelt and mesentery weights, whereas the treatment AC15 increased $(P<0.05)$ spleen and lung weight as a percentage of carcass weight. In regards to the protein content of the 9-11th ribs, the treatment AT15 was similar to the control, but the AC15 and TC30 were lower $(P<0.05)$ than the control. Lambs in the treatment groups showed a normal histology of ileum, sub-mucosa and Peyer's patches. It could be concluded that AT or AC can replace $50 \%$ of berseem in the diet of Barki lambs without compromising lamb growth performance.
\end{abstract}

(c) 2015 Elsevier B.V. All rights reserved.

\footnotetext{
* Corresponding author. Tel.: +521 72229655 42; fax: +5217221806194.

E-mail address: asalem70@yahoo.com (A.Z.M. Salem).
}

\section{Introduction}

Berseem (Trifolium alexandrinum) is the most important leguminous forage crop in the Mediterranean region and the Middle-East. In Egypt, the annually cultivated area is up to 1.3 million hectares (Heuzé et al., 2014). The crop provides green feed to ruminants during growing seasons, but can also be made into hay for animals during other seasons. However, this 
forage crop has the same growing season as wheat (Triticum aestivum) and thus competes for arable land, which is scarce in the region with wheat production, which directly provides food to humans. Thus, there is a need to find an alternative to completely, or at least partially, replace berseem.

The Mediterranean region and the Middle-East are in the arid and semi-arid zones and moreover, some arable land is salinised. Such environments limit the number of plant species that could be grown in the region. As a result, options for the replacement of berseem are limited. Recently, people have been aware of the value of halophytic forage shrubs as animal feeds (Shaker, 2014). For example, saltbush Atriplex spp. and shrub plants Acacia spp. received special attention for their potential to be livestock feeds (Salem et al., 2012, 2015; Shaker, 2014; Alsersy et al., 2015). The plants of these two genera can be grown in a wide range of saline and arid environments (Salem et al., 2012; Shaker, 2014; Alsersy et al., 2015). Hence, there is a great potential for them to be animal feeds.

Atriplex contains a high level of crude protein and plant secondary metabolites (Alsersy et al., 2015; Salem et al., 2015). These secondary metabolites include tannins, oxalates, saponins and alkaloids (Salem et al., 2012). At appropriate concentrations, these compounds have positive effects on nutrient utilisation and animal performance. For example, low concentrations of tannins and saponins in Atriplex protect dietary proteins from degradation in the rumen, have a defaunation effect and decrease methane production. As a result, either grazing or stall-fed ruminants fed Atriplex had improved animal performance (Ben Salem et al., 2010). Atriplex nummularia (AT) has a balanced amino acid composition of methionine and lysine, and the two essential amino acids are higher than those in cereals and are close to the level of the $\mathrm{FAO} / \mathrm{WHO}$ reference protein score (Khalil et al., 1986).

Acacia saligna (AC) is the most popular species of Acacia owing to its tolerance to drought and salinised soil conditions. It has a high green biomass and high crude protein (CP) content, and, thus, is of high nutritive value (Degan et al., 1997; Salem, 2005). But the plant contains a large amount of condensed tannins and consequently cannot be served as a sole feed for sheep (Degan et al., 1997; Salem et al., 2006). Condensed tannins form precipitates with proteins, resulting in the formation of indigestible tannin-protein complexes (Degan et al., 1997). Tannins also form complexes with soluble carbohydrates, cellulose, hemicelluloses and amino acids, reducing their digestibilities (Barry, 1985). However, if the plant is used as a dietary ingredient accounting for a small proportion of feed intake, condensed tannins would be diluted and beneficial effects appear and negative effects are eliminated.

Therefore, this study aimed to evaluate the viability of partial or complete replacement of berseem hay in the diet of Barki lambs with AT and/or AC. Animal biochemical, physiological and histological parameters, growth performance and carcass characteristics were employed for the evaluation of such replacement.

\section{Materials and methods}

Experimental animals were cared and handled in accordance with the Guide for the Care and Use of Agricultural Animals in Agricultural Research and Teaching (FASS, 1999).

\subsection{A. nummularia and A. saligna preparation}

Leaves and stems of fresh nursery plants of saltbush $A$. nummularia and shrub plant $A$. saligna were collected from the North-western desert region of Borg El-Arab, Alexandria, sun-dried, chopped to $3-5 \mathrm{~cm}$ in length and stored in a dry environment.

\subsection{Animals and treatments}

Thirty six growing male Barki lambs, an indigenous breed in Egypt, Libya and Tunisia, with live body weight (BW) of $26.5 \pm 1.1 \mathrm{~kg}$ and an age of $13 \pm 1.1$ months, were used. All animals lived under the same hygienic conditions and were managed equally. Prior to the experiment, the animals were treated against internal and external parasites (Albendazole $10 \mathrm{mg} / \mathrm{kg}$ BW; Zoetis Inc., Kalamazoo, MI, USA). Lambs were randomly allocated into four treatment groups of nine and individually housed in cages.

Lambs were fed with diets which were formulated to meet their maintenance and growth requirements (NRC, 1985). Before the experiment, lambs were fed on a diet of concentrates and berseem hay at a ratio of $50: 50$ on a dry matter (DM) basis. The control diet contained concentrates and berseem hay at a ratio of 70:30 on a DM basis. The treatment diets were the same as the control, but half of the berseem hay was replaced with either A. nummularia (AT15) or A. saligna (AC15), or berseem hay was totally replaced with AT and AC at a 1:1 ratio (TC30). Lambs were adapted to their designated diets for two weeks before measurements. Ingredients and the chemical composition of the diets are presented in Table 1.

\subsection{Growth performance}

Lambs were weighed every two weeks before morning feeding. Period 1 was defined as from week 0 to week 2 , period 2 from week 2 to week 4 , and so on. Mean daily body weight gain was calculated by the difference between two consecutive weighings. Feed offered and refused was quantified daily for each lamb to calculate feed consumption. Feed conversion ratio was expressed as feed consumption per unit of body weight gain. A fixed amount of water was available daily and the remaining water was weighed daily for each lamb. A bucket with the same amount of water offered was placed in the animal shed to estimate water evaporation for the calibration of water consumption.

\subsection{Blood chemistry}

Four lambs per treatment were randomly chosen for blood collection on days 35 and 70 of the experiment. About $10 \mathrm{~mL}$ of blood each lamb was collected from the jugular vein immediately before morning feeding. Collected blood was filled into a tube (BD Vacutainer ${ }^{\circledR}$ Tubes, NJ, USA) with heparin for anticoagulant and directly centrifuged at $4000 \times \mathrm{g}$ at $4{ }^{\circ} \mathrm{C}$ for $20 \mathrm{~min}$. Plasma was separated into a glass vial and frozen at $-20^{\circ} \mathrm{C}$ until analysis.

\subsection{Ruminal fermentation parameters}

Rumen samples were collected from the same blood sampled lambs during slaughtering according to the method described in Kholif et al. (2014). Briefly, about $100 \mathrm{~mL}$ of rumen contents was sampled and strained through four layers of cheesecloth. Ruminal $\mathrm{pH}$ was immediately determined using a digital pH metre (GLP 22, Crison Instruments, Barcelona, Spain). Strained rumen samples were filled into $45-\mathrm{mL}$ glass bottles with a few drops of toluene and paraffin oil added to just cover the surface and stored at $-18^{\circ} \mathrm{C}$ for later analyses of ammonia- $\mathrm{N}$ and volatile fatty acids.

\subsection{Slaughter procedure}

Lambs were fasted for $18 \mathrm{~h}$ and then slaughtered at a commercial slaughterhouse. Body weight was obtained for all lambs immediately before slaughtering. Hot carcass weight including fat tail and kidney fat was determined immediately after dressing. Heads, legs, lungs, hides, hearts, livers and full digestive tract were weighed as well. The 9-11th ribs were separated from the right side of each carcass and physically divided into meat, bone and fat. Meat samples were ground through a 4$\mathrm{mm}$ plate for each animal, mixed and reground. Then, 30-40 g of ground meat from each lamb was placed in a plastic bag and stored at $-20^{\circ} \mathrm{C}$ for chemical analysis.

\subsection{Histological parameters}

Immediately after post-mortem examination, tissue specimens from the small intestine were rapidly fixed in $10 \%$ neutral buffered formalin solution for at least $24 \mathrm{~h}$. The fixed specimens were dehydrated through ascending grades of ethanol, cleared in chloroform and embedded in paraffin wax at $60^{\circ} \mathrm{C}$. From paraffin blocks, $5-\mu \mathrm{m}$ thick sections were obtained. These sections were stained using haematoxylin and eosin according to the method of Culling (1983) and examined using bright-field microscopy.

\subsection{Chemical analyses}

The contents of DM, ash, N, crude fibre (CF) and ether extract (EE) in feed samples were analysed by the method of AOAC (1997), neutral detergent fibre (NDF) and acid detergent fibre (ADF) by the method of Van Soest et al. (1991) using ANKOM200 fibre Analyser unit (ANKOM 
Table 1

Diet ingredients and chemical composition ( $\mathrm{g} / \mathrm{kg}$ dry matter).

\begin{tabular}{|c|c|c|c|c|c|c|c|}
\hline & Berseem hay & AT & $A C$ & Control & AT15 & AC15 & TC30 \\
\hline \multicolumn{8}{|l|}{ Ingredients } \\
\hline Berseem (Trifolium alexandrinum) hay & & & & 300 & 150 & 150 & 0 \\
\hline Atriplex nummularia hay & & & & 0 & 150 & 0 & 150 \\
\hline Acacia saligna hay & & & & 0 & 0 & 150 & 150 \\
\hline Barley grain & & & & 265 & 265 & 265 & 265 \\
\hline Wheat bran & & & & 250 & 250 & 250 & 250 \\
\hline Soya bean meal & & & & 100 & 100 & 100 & 100 \\
\hline Molasses & & & & 55 & 55 & 55 & 55 \\
\hline $\mathrm{NaHCO}_{3}$ & & & & 20 & 20 & 20 & 20 \\
\hline $\mathrm{NaCl}$ & & & & 5 & 5 & 5 & 5 \\
\hline Mineral and vitamin mixture ${ }^{b}$ & & & & 5 & 5 & 5 & 5 \\
\hline \multicolumn{8}{|l|}{ Chemical composition } \\
\hline Organic matter & 902 & 754 & 863 & 890 & 802 & 887 & 872 \\
\hline Crude protein & 167 & 189 & 176 & 155 & 161 & 169 & 161 \\
\hline Ether extract & 20.1 & 11.1 & 11.6 & 17.0 & 12.5 & 18.9 & 17.6 \\
\hline Crude fibre & 200 & 268 & 228 & 148 & 179 & 168 & 177 \\
\hline Non-fibre carbohydrates ${ }^{c}$ & 294 & 89 & 236 & 332 & 222 & 299 & 288 \\
\hline Neutral detergent fibre & 421 & 465 & 439 & 386 & 407 & 400 & 405 \\
\hline Acid detergent fibre & 281 & 265 & 238 & 191 & 189 & 185 & 183 \\
\hline \multicolumn{8}{|l|}{ Secondary compounds } \\
\hline Total phenolics & & 113 & 61 & & & & \\
\hline Saponins & & 124 & 24 & & & & \\
\hline Alkaloids & & 2.3 & 3.2 & & & & \\
\hline Aqueous fraction $^{\mathrm{d}}$ & & 475 & 68 & & & & \\
\hline
\end{tabular}

a Diets contained $70 \%$ concentrates and $30 \%$ berseem hay (control); $70 \%$ concentrates $+15 \%$ berseem hay $+15 \%$ Atriplex (AT 15 ); $70 \%$ concentrates $+15 \%$ berseem hay $+15 \%$ Acacia (AC15); or 70\% concentrates $+15 \%$ Atriplex $+15 \%$ Acacia (TC30). Atriplex (AT); Acacia (AC).

b Mineral and vitamin mixture (/kg): Cu, 8 mg; Fe, 35 mg; Mn, 80 mg; Se, 0.6 mg; Zn, 60 mg; vitamin A, 12,000 IU; vitamin D3, 2500 ICU; vitamin E, 20 IU; menadione, $1.3 \mathrm{mg}$; riboflavin, $5.5 \mathrm{mg}$; vitamin B12, $10 \mu \mathrm{g}$; vitamin B6, $3 \mathrm{mg}$; thiamine, $3 \mathrm{mg}$; folic acid, $1.0 \mathrm{mg}$; D-biotin, $50 \mu \mathrm{g}$; Ca-pantothenate, $1 \mathrm{mg}$; nicotinic acid, $50 \mathrm{mg}$; choline chloride, $600 \mathrm{mg}$.

c Non-fibre carbohydrates calculated by difference [100 - (\%NDF +\%CP +\%fat $+\% \mathrm{ash})]$.

d Aqueous fraction (lectins, polypeptides and starch).

Technology Corporation, Macedon, NY, USA). The analysis of NDF was conducted without $\alpha$-amylase but with sodium sulphite. Both NDF and ADF were expressed without residual ash. Meat samples were analysed for DM, protein, ether extract and ash according to AOAC (1997). The secondary metabolite concentrations in AT and AC were determined as described in Salem et al. (2014). Ruminal ammonia-N concentration was determined according to the method of Gips and Wibbens-Alberts (1968) and ruminal volatile fatty acids by the method of Warner (1964).

\subsection{Statistical analysis}

Dry matter intake, water consumption, daily weight gain and feed conversion were analysed with diet type, period (as repeated measurement) and their interaction (diet $\times$ period) as the experimental factors having fixed effects using PROC MIXED of SAS (SAS Inst. Inc., Cary, NC, 2002) in two-way ANOVA according to the following statistical model:

$Y_{i j k}=\mu+D_{i}+T_{j}+(D \times T)_{i j}+A_{k}+e_{i j k}$

where $Y_{i j k}$ is the dry matter intake, water consumption, daily weight gain or feed conversion, respectively, $\mu$ is the overall mean, $D_{i}$ is the fixed effect of diet $(i=4), T_{j}$ is the fixed effect of period $(j=5),(D \times T)_{i j}$ is the fixed effect of interaction between diet and period, $A_{k}$ is the random effect of animal $(k=9)$, and $e_{i j k}$ is the random residual error. Significance was declared at a level of $P<0.05$ and trend at $P \leq 0.10$.

The remaining data obtained were analysed using one-way ANOVA according to the following statistical model:

$Y_{i j}=\mu+D_{i}+A_{j}+e_{i j}$

where $Y_{i j}$ is the observation, $\mu$ is the overall mean, $D_{i}$ is the fixed effect of diet, $A_{j}$ is the random effect of animal, and $e_{i j}$ is the random residual error. The comparisons among treatments were performed with Duncan's multiple range test.

\section{Results}

\subsection{Feed intake and growth performance}

Interaction effects $(P<0.01)$ occurred between period $\times$ diet for DM intake, daily weight gain and feed conversion. Moreover, period affected $(P<0.01)$ both daily weight gain and feed conversion. Replacing berseem hay with AT and AC increased $(P<0.05)$ DM intake (g/lamb/day) during the last two weeks, water consumption (L/lamb/day) during the last six weeks, daily live weight gain ( $\mathrm{g} / \mathrm{lamb} /$ day) through the whole experimental period and feed conversion during the second and last two weeks (Table 2).

Lambs of AC15 had increased DM intake $(P<0.01)$ during the periods of weeks $6-8$ and weeks $8-10$ compared to other periods. On the contrary, TC30 lambs showed increased DM intake $(P<0.05)$ during the period of weeks 2-4 compared to other periods. Moreover, the daily weight gain and feed conversion were affected by period $(P<0.05)$; the highest daily gain was achieved during the first period (i.e., weeks 0-2) compared to other periods (Table 2).

\subsection{Ruminal fermentation and blood parameters}

Inclusion of AT or AC in the diets decreased $(P<0.01)$ the total volatile fatty acid concentration compared to the control, but ruminal ammonia- $\mathrm{N}$ concentration was not affected. 
Table 2

Feed intake and growth performance in growing Barki lambs fed the experimental diets ${ }^{\mathrm{a}}$ containing Atriplex and/or Acacia ( $n=9$ per group).

\begin{tabular}{|c|c|c|c|c|c|c|c|c|}
\hline & \multirow[t]{2}{*}{ Control } & \multirow[t]{2}{*}{ AT15 } & \multirow[t]{2}{*}{ AC15 } & \multirow[t]{2}{*}{ TC30 } & \multirow[t]{2}{*}{ SEM } & \multicolumn{3}{|l|}{$P$ value } \\
\hline & & & & & & Diet & Period & Period $\times$ diet \\
\hline Initial body weight (kg) & 26.2 & 26.4 & 25.9 & 26.9 & 1.48 & $N S^{b}$ & & \\
\hline Final body weight (kg) & 36.6 & 39.0 & 37.3 & 35.8 & 1.06 & NS & & \\
\hline \multicolumn{9}{|l|}{ DM intake (g/lamb/day) } \\
\hline Week 0-2 & $952 c$ & $1057 b$ & 1119ABa & $810 \mathrm{ABC}$ & 47.5 & 0.015 & & \\
\hline Week 2-4 & $810 c$ & $1150 a$ & $802 \mathrm{BC}$ & $1097 \mathrm{Ab}$ & 48.3 & 0.031 & & \\
\hline Week 4-6 & 1136a & $882 \mathrm{c}$ & $851 \mathrm{Bc}$ & $950 \mathrm{ABb}$ & 57.1 & 0.023 & & \\
\hline Week 6-8 & $1176 a$ & $1004 b$ & 1204Aa & $884 \mathrm{ABC}$ & 56.5 & 0.042 & & \\
\hline Week 8-10 & $1078 c$ & $1172 b$ & $1228 \mathrm{Aa}$ & $710 \mathrm{Bd}$ & 44.5 & 0.022 & & \\
\hline SEM & 133.1 & 83.5 & 81.9 & 85.2 & & 43.8 & 49.0 & 98.0 \\
\hline$P$ value & NS & NS & 0.008 & 0.032 & & 0.032 & NS & $<0.001$ \\
\hline \multicolumn{9}{|c|}{ Water consumption ( $\mathrm{L} / \mathrm{lamb}$ /day) } \\
\hline Week 0-2 & 3.36 & 3.05 & 3.80 & 3.46 & 0.153 & NS & & \\
\hline Week 2-4 & 3.31 & 3.11 & 3.50 & 3.00 & 0.147 & NS & & \\
\hline Week 4-6 & $3.41 \mathrm{c}$ & $3.95 a$ & $3.78 b$ & 3.90a & 0.141 & 0.040 & & \\
\hline Week 6-8 & $3.45 c$ & $4.00 \mathrm{a}$ & $3.13 d$ & 3.79ab & 0.156 & 0.044 & & \\
\hline Week 8-10 & $3.30 \mathrm{~b}$ & $3.92 \mathrm{a}$ & $3.10 \mathrm{c}$ & $3.81 \mathrm{a}$ & 0.150 & 0.001 & & \\
\hline SEM & 0.408 & 0.366 & 0.348 & 0.405 & & 0.171 & 0.191 & 0.383 \\
\hline$P$ value & NS & NS & NS & NS & & NS & NS & NS \\
\hline \multicolumn{9}{|c|}{ Daily weight gain (g/lamb/day) } \\
\hline Week 0-2 & $207 \mathrm{Ab}$ & $246 \mathrm{Aa}$ & $248 \mathrm{Aa}$ & $184 \mathrm{Ac}$ & 11.4 & 0.041 & & \\
\hline Week 2-4 & $116 \mathrm{Bc}$ & 176ABab & $183 \mathrm{ABa}$ & $161 \mathrm{ABb}$ & 10.5 & 0.011 & & \\
\hline Week 4-6 & 149ABa & $118 \mathrm{Bb}$ & 119Bb & $117 \mathrm{ABCb}$ & 8.0 & 0.048 & & \\
\hline Week 6-8 & 149ABa & 135Bab & $121 \mathrm{Bb}$ & 104BCc & 9.4 & 0.024 & & \\
\hline Week 8-10 & $125 \mathrm{Bc}$ & $228 \mathrm{Aa}$ & 147Bb & $71 \mathrm{Cd}$ & 5.8 & 0.024 & & \\
\hline SEM & 16.7 & 22.0 & 21.6 & 17.2 & & 8.7 & 9.7 & 19.4 \\
\hline$P$ value & 0.004 & $<0.001$ & $<0.001$ & $<0.002$ & & $<0.001$ & $<0.001$ & 0.002 \\
\hline \multicolumn{9}{|c|}{ Feed conversion (kg feed/kg live weight gain) } \\
\hline Week 0-2 & $4.59 \mathrm{~B}$ & $4.30 \mathrm{C}$ & $4.51 \mathrm{C}$ & $4.41 \mathrm{~B}$ & 0.918 & 0.462 & & \\
\hline Week 2-4 & $6.95 \mathrm{Aa}$ & $6.52 \mathrm{ABa}$ & $4.38 \mathrm{Cb}$ & $6.83 \mathrm{ABa}$ & 0.820 & 0.026 & & \\
\hline Week 4-6 & $7.61 \mathrm{~A}$ & $7.47 \mathrm{~A}$ & $7.13 \mathrm{~B}$ & $8.11 \mathrm{~A}$ & 0.803 & 0.265 & & \\
\hline Week 6-8 & $7.91 \mathrm{~A}$ & $7.40 \mathrm{~A}$ & $9.72 \mathrm{~A}$ & $8.47 \mathrm{~A}$ & 0.778 & 0.092 & & \\
\hline Week 8-10 & 8.62Aa & $5.14 \mathrm{BCb}$ & 8.34ABa & $10.04 \mathrm{Aa}$ & 0.778 & 0.010 & & \\
\hline SEM & 0.499 & 0.564 & 0.495 & 0.847 & & 0.276 & 0.309 & 0.618 \\
\hline$P$ value & $<0.001$ & $<0.001$ & $<0.001$ & $<0.001$ & & 0.005 & $<0.001$ & $<0.001$ \\
\hline
\end{tabular}

${ }^{a}$ Diets contained $70 \%$ concentrates and 30\% berseem hay (control); $70 \%$ concentrates $+15 \%$ berseem hay $+15 \%$ Atriplex (AT15); $70 \%$ concentrates $+15 \%$ berseem hay $+15 \%$ Acacia (AC15) or $70 \%$ concentrates $+15 \%$ Atriplex $+15 \%$ Acacia (TC30).

${ }^{b}$ Not significant $(P>0.05)$.

$(A, B, C)$ means within in the same column with different letters differ significantly among periods $(P<0.05)$.

(a,b,c,d) means within in the same row with different letters differ significantly among treatments $(P<0.05)$.

The experimental diets containing either AT or AC decreased $(P<0.05)$ the concentrations of cholesterol, low density lipoproteins and glucose in blood. The treatments AT15 and AC15 had greater $(P<0.05)$ serum urea concentration compared to the control. However, this effect disappeared when berseem hay was completely replaced with AT and AC (TC30). Differences in blood total protein, albumin, globulin and high density lipoproteins were not observed $(P>0.05)$ among the diets (Table 3$)$.

\subsection{Carcass characteristics}

As a percentage of carcass weight, feeding lambs on AT15 diet increased $(P<0.05)$ gut fill, pelt and mesentery. Feeding lambs on AC15 diet increased $(P<0.05)$ the weights of spleen, lung, pelts and mesentery and dressing percentage in comparison with the control diet. Slaughter body weight and carcass weight both did not differ $(P>0.05)$ among the diets (Table 4).

No differences were detected among treatments regarding the physical and chemical composition of the 9-11th ribs with an exception of protein content $(P<0.05)$. Replacement of berseem hay with AT (AT15) did not significantly reduce protein content, but inclusion of AC alone (AC15) or in combination with AT (TC30) greatly reduced the protein content (Table 4 ).

\subsection{Intestinal histopathology}

All experimental lambs showed a normal histology of ileum, sub-mucosa and Peyer's patches. Compared to the control diet (Fig. 1), lambs fed AT15 (Fig. 2), AC15 (Fig. 3) and TC30 (Fig. 4) had some reactive alterations in ileum.

\section{Discussion}

\subsection{Feed intake and water consumption}

Occurrence of interaction between period and diet for DM intake showed that the DM intake differed with period progress. For the AC15 treatment, the highest 
Table 3

Ruminal fermentation and blood parameters of growing Barki lambs fed the experimental diets ${ }^{\mathrm{a}}$ containing Atriplex and/or Acacia ( $n=4$ per group).

\begin{tabular}{|c|c|c|c|c|c|c|}
\hline & Control & AT15 & AC15 & TC30 & SEM & $P$ value \\
\hline \multicolumn{7}{|l|}{ Ruminal fermentation parameters } \\
\hline Volatile fatty acids (mmol/100 mL) & $16.2 \mathrm{a}$ & 14.8ab & $15.4 \mathrm{a}$ & $14.2 \mathrm{~b}$ & 1.36 & 0.001 \\
\hline Ammonia-N (mg/100 mL) & 51.3 & 46.3 & 59.0 & 43.0 & 7.10 & $\mathrm{NS}^{\mathrm{b}}$ \\
\hline \multicolumn{7}{|l|}{ Blood parameters $(\mathrm{mg} / \mathrm{dL})$} \\
\hline Total protein & 6.02 & 6.77 & 6.04 & 5.64 & 0.382 & NS \\
\hline Albumin & 3.81 & 3.93 & 3.34 & 3.33 & 0.320 & NS \\
\hline Globulin & 2.21 & 2.84 & 2.71 & 2.31 & 0.449 & NS \\
\hline Cholesterol & $135 a$ & $86 d$ & $102 c$ & $112 b$ & 2.3 & 0.023 \\
\hline Low density lipoproteins & 83.7a & $48.7 d$ & $60.3 c$ & $71.0 \mathrm{~b}$ & 1.98 & 0.033 \\
\hline High density lipoproteins & 28.4 & 30.5 & 26.7 & 28.8 & 1.37 & NS \\
\hline Urea & $32.9 \mathrm{c}$ & $51.1 \mathrm{a}$ & $55.2 \mathrm{a}$ & $39.3 b$ & 2.17 & 0.033 \\
\hline Glucose & $101.2 \mathrm{a}$ & $77.1 \mathrm{c}$ & $70.1 d$ & $93.9 \mathrm{~b}$ & 2.48 & 0.022 \\
\hline
\end{tabular}

a Diets contained $70 \%$ concentrates and 30\% berseem hay (control); $70 \%$ concentrates $+15 \%$ berseem hay $+15 \%$ Atriplex (AT15); $70 \%$ concentrates $+15 \%$ berseem hay $+15 \%$ Acacia (AC15) or $70 \%$ concentrates $+15 \%$ Atriplex $+15 \%$ Acacia (TC30).

b Not significant $(P>0.05)$.

(a,b,c,d) means within the same row with different letters differ significantly among treatments $(P<0.05)$.

feed consumption occurred during the last two periods from week 6 to week 10, which may be related to adaptability to the AC15 diet. However, for the TC30 treatment, feed consumption increased during the period from week 2 to week 4 and decreased gradually with period. Previous studies illustrated that the increased level of salt in the diet from AT and AC can limit feed intake and result in a poor efficiency of digestible energy (Masters et al., 2005). The presence of plant secondary metabolites may also restrict nutrient utilisation causing reduced feed intake (Alsersy et al., 2015; Salem et al., 2015). The results obtained in the present study showed that feed intake during the first six weeks was improved by about $6.6,11.3$ and $8.1 \%$ for AC15, AT15 and TC30, respectively versus the control diet. However, during the last four weeks the intake decreased. Moujahed et al. (2005) reported a decrease in intake with increasing level of AC in the diet of sheep and goats. This decrease in intake was explained by the palatability and increased tannin intake, which along with period increased rumen retention time, decreased intestine motility and

Table 4

Carcass characteristics, physical and chemical composition of the 9-11th ribs of growing Barki lambs fed the experimental diets ${ }^{\mathrm{a}}$ containing Atriplex and/or Acacia ( $n=9$ per group).

\begin{tabular}{|c|c|c|c|c|c|c|}
\hline & Control & AT15 & AC15 & TC30 & SEM & $P$ value \\
\hline \multicolumn{7}{|l|}{ Carcass characteristics } \\
\hline Slaughter body weight (kg) & 36.7 & 39.0 & 37.3 & 35.8 & 3.09 & $\mathrm{NS}^{\mathrm{b}}$ \\
\hline Carcass weight $(\mathrm{kg})$ & 15.9 & 16.1 & 15.0 & 15.8 & 1.84 & NS \\
\hline Dressing $(\mathrm{g} / \mathrm{kg})$ & $433 b$ & $413 c$ & $402 d$ & $440 \mathrm{a}$ & 2.7 & 0.022 \\
\hline \multicolumn{7}{|l|}{ Organs weight ( $\mathrm{g} / \mathrm{kg}$ carcass) } \\
\hline Full gut & $171.3 \mathrm{c}$ & 217.0a & $177.3 \mathrm{c}$ & $194.5 \mathrm{~b}$ & 5.96 & 0.032 \\
\hline Empty gut & 64.1 & 60.8 & 64.3 & 64.8 & 2.37 & NS \\
\hline Pelt & $91.1 \mathrm{~b}$ & 138.0a & $93.5 \mathrm{~b}$ & $136.6 a$ & 3.60 & 0.001 \\
\hline Liver & 14.7 & 16.2 & 14.7 & 14.8 & 2.10 & NS \\
\hline Heat & 3.5 & 3.6 & 3.5 & 3.7 & 0.12 & NS \\
\hline Heart fat & 1.7 & 1.5 & 1.4 & 2.1 & 0.72 & NS \\
\hline Spleen & $3.1 \mathrm{a}$ & $1.9 \mathrm{~b}$ & $3.1 \mathrm{a}$ & $2.1 \mathrm{~b}$ & 0.03 & 0.033 \\
\hline Lung & $11.5 \mathrm{~b}$ & $11.3 \mathrm{~b}$ & $12.1 \mathrm{a}$ & $9.8 \mathrm{c}$ & 0.18 & 0.041 \\
\hline Mesentery & $18.2 \mathrm{~b}$ & $20.4 a$ & $14.0 \mathrm{c}$ & $19.9 \mathrm{a}$ & 1.14 & 0.011 \\
\hline \multicolumn{7}{|c|}{ Characteristics of the 9-11th ribs (g) } \\
\hline Weight of the 9-11th ribs & 370 & 420 & 380 & 360 & 38.5 & NS \\
\hline Meat weight & 213 & 240 & 203 & 180 & 24.3 & NS \\
\hline Subcutaneous weight & 55.5 & 69.0 & 70.0 & 68.0 & 10.01 & NS \\
\hline Weight of fat between mussels & 29.7 & 30.9 & 35.0 & 29.4 & 1.06 & NS \\
\hline Total fat weight & 85.2 & 99.9 & 105.0 & 107.4 & 13.02 & NS \\
\hline Bone weight & 71.9 & 79.7 & 72.2 & 72.6 & 6.03 & NS \\
\hline \multicolumn{7}{|c|}{ Chemical composition of the $9-11$ th ribs (g/kg) } \\
\hline Dry matter & 516 & 466 & 484 & 512 & 24.9 & NS \\
\hline Protein & $194 a$ & $189 a$ & $175 \mathrm{~b}$ & $173 \mathrm{~b}$ & 6.2 & 0.011 \\
\hline Ether extract & 282 & 337 & 334 & 307 & 22.6 & NS \\
\hline Ash & 7.8 & 7.9 & 7.6 & 8.2 & 0.25 & NS \\
\hline
\end{tabular}

${ }^{a}$ Diets contained $70 \%$ concentrates and $30 \%$ berseem hay (control); $70 \%$ concentrates $+15 \%$ berseem hay $+15 \%$ Atriplex (AT15); $70 \%$ concentrates $+15 \%$ berseem hay $+15 \%$ Acacia (AC15) or $70 \%$ concentrates $+15 \%$ Atriplex $+15 \%$ Acacia (TC30).

b Not significant $(P>0.05)$.

(a,b,c,d) means within the same row with different letters differ significantly among treatments $(P<0.05)$. 


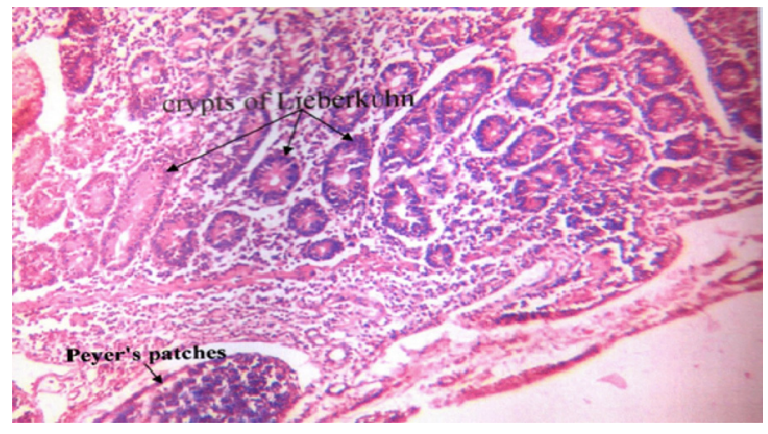

Fig. 1. Photomicrograph of ileum of control lambs stained with haematoxylin and eosin $(160 \times)$ : normal histology.

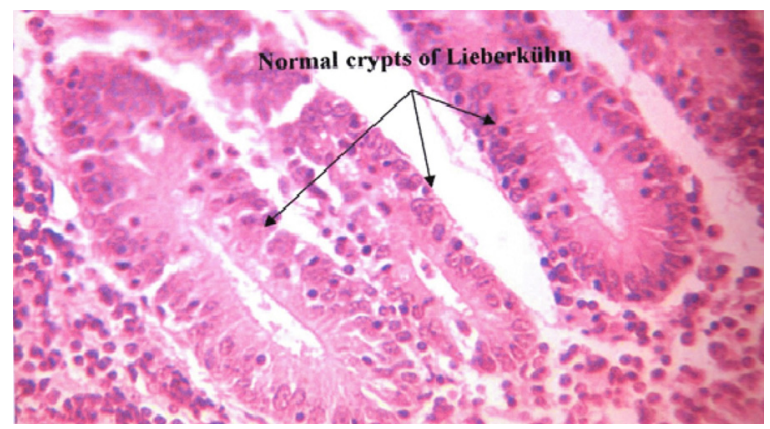

Fig. 2. Photomicrograph of ileum of AT15 lambs stained with haematoxylin and eosin $(160 \times)$ : normal histology.

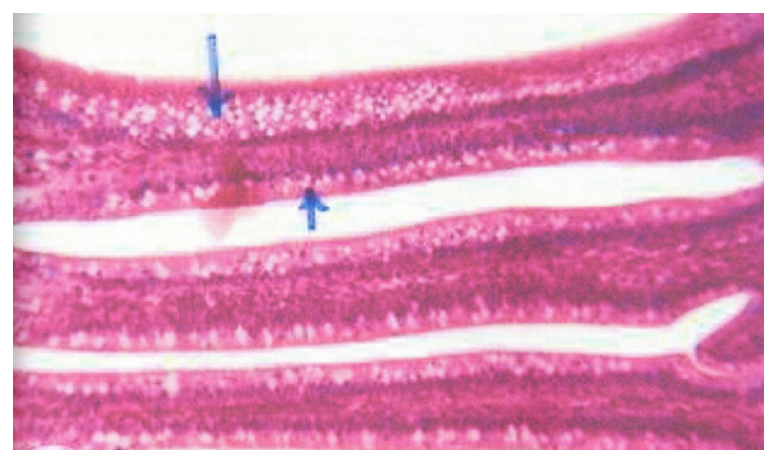

Fig. 3. Photomicrograph of ileum of AC15 lambs stained with haematoxylin and eosin $(160 \times)$ : normal elongated villi with normal excess of goblet cell formation (arrows).

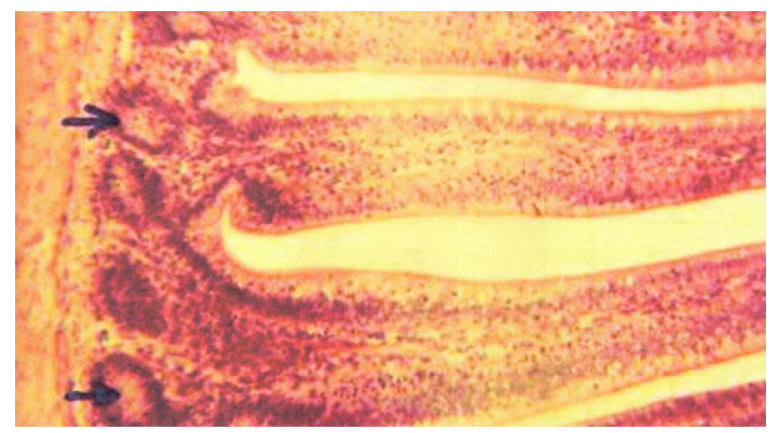

Fig. 4. Photomicrograph of ileum of TC30 lambs stained with haematoxylin and eosin $(160 \times)$ : normal histology. increased retention time for the digesta in the gut (Garcia et al., 1999). Moreover, the highest intake was recorded with AT and this might be related to high energy content in the AT diet (Du Toit et al., 2006). However, Abu-Zanat (2005) reported that the inclusion of AT in the diet to substitute $50 \%$ of alfalfa hay had no effects on feed intake.

Increased water consumption was observed with lambs fed the experimental diets specially after feeding the diets for four weeks. This result is consistent with Bhatti (2009) who found that Kajli lambs drank more water when Atriplex amnicola hay was supplemented in the diet. Increased water consumption may result from the high contents of ash and salt in AT and AC. The greater salt consumed would force animals to consume more water to excrete excess salt and an increase in water recycling consequently influences rumen physiology and metabolism (Abu-Zanat and Tabbaa, 2006). To relieve the effect, feeding animals with a mixture of shrub species to dilute the high salt content may be recommended as a farming practice.

\subsection{Rumen fermentation}

A substantial amount of $\mathrm{N}$ in AT and AC is present in non-protein compounds which are degraded by rumen microflora to produce ammonia-N. Adequate quantity of energy from molasses and barley would enhance feed degradation and utilisation by microorganisms and the host animal (Le Houérou, 1992). This hypothesis explains the unchanged values of ruminal ammonia- $\mathrm{N}$ in the rumen of lambs fed diets with higher protein content. Newbold et al. (1996) concluded that decreased ruminal ammonia$\mathrm{N}$ concentration is mainly due to reduced proteolysis, reduced degradation of peptides and deamination of amino acids in the rumen. Decreased volatile fatty acids with the experimental diets may be due to the diluted ruminal contents as a result of increased water consumption for animals fed both AC and AT.

\subsection{Blood chemistry}

No differences in blood total protein and globulin were observed among treatments. These results were in agreement with those reported by Shaker (2014) who found no differences in these parameters when sheep were fed AT. The slight increase in total proteins with AT15 and AC15 could be attributed to the increased CP. Kumar et al. (1980) reported a positive correlation between dietary protein and plasma protein concentrations.

Shaker (2014) noted that feeding sheep salt tolerant plants decreased $(P<0.01)$ plasma glucose concentration by $17.9 \%$, which might be attributed to the tannin content in these plants. High salt in these salt tolerant forages might reduce glucose concentration.

Decreased cholesterol concentrations were observed with the experimental diets. This may be due to the presence of tannins which interfere with lipid digestion through forming complexes with fatty acids (Romero et al., 2000), decreasing cholesterol absorption and increasing fat excretion (Bravo et al., 1993). However, saponins may cause the same effects (Fayed et al., 2010) through inhibiting cholesterol absorption, causing reductions in plasma 
high-density lipoprotein and in cholesterol fraction (Morehouse et al., 1999). The same trend was observed with other reports with Barki rams (Shaker, 2014).

Urea and creatinine are the two main nitrogenous compounds excreted from the kidneys. Accordingly, any change in their concentrations would reflect impaired glomerular filtration and/or insufficiency of renal tubules (Kaneko, 1989). Furthermore, urea is the major $\mathrm{N}$ containing metabolic product of protein catabolism, accounting for more than $75 \%$ of the non-protein $\mathrm{N}$ excreted. In addition, urea production is also dependent on several variables such as diet and hepatic synthesis. The present results revealed that an increase in mean concentration of urea was observed in animals fed the experimental diets. The increased urea concentration could be due to the presence of higher contents of protein and non-protein. Cenci et al. (2006) showed that the values of total protein, urea, phosphorus and calcium concentrations in the serum were within the normal range when animals were fed AC. Moreover, Arieli et al. (1989) reported that urea concentration in plasma was higher by about 30\% when sheep consumed saltbush versus a control diet.

\subsection{Growth performance}

Period affected lambs daily weight gain, where the highest gain was achieved during the first two weeks. This might be related to the lack of gut fill due to the weak impact of the forages during the first period of consumption. Compensatory growth during the first period cannot be ignored as the lambs were fed on diets containing concentrates and hay at a ratio of 70:30 on a DM basis during the experiment, which had higher nutritive values than the diet containing concentrates and hay at a ratio of 50:50 before the experiment. Lambs fed either AC15 or AT15 had an improved daily body weight gain compared with other treatment lambs. These results underlined the potential of salt tolerant plants as a dietary component to fulfil animal requirements for growth. The improved body weight gain may be due to increased feed intake and digestibility (Alsersy et al., 2015; Salem et al., 2015). In addition, complementary effects may occur between the presence of non-protein $\mathrm{N}$ in both AT and AC and metabolisable energy of barley grains and molasses in the diet (Pearce et al., 2010). Moreover, the low content of tannins in the diets can improve $\mathrm{N}$ utilisation through the protection of dietary proteins from rumen degradation (Salem et al., 2006). However, Shaker (2014) found that body weight was not affected by feeding a salt tolerant fodder crop mixture containing AT. Also, Abu-Zanat (2005) reported that animals eating a diet having lucerne hay partially replaced with A. nummularia or Atriplex halimus had lower growth rate than those consuming a diet where alfalfa hay was not replaced. In our study, the diet with berseem hay completely replaced with AT and AC (TC30) reduced body weight gain. These negative results in the previous and present studies may be attributed to decreased DM intake and blood albumin, which might result from too high contents of salt and tannin in the diet, causing reduced N digestibility (Kumar et al., 1980; Alsersy et al., 2015).

\subsection{Carcass traits}

Improved carcass weights were observed with the experimental diets of AC15 and AT15. This response can be attributed to increased $\mathrm{CP}$ content and improved voluntary feed intake. For both diets, barley and molasses were the main energy sources. The presence of readily available energy sources can improve the utilisation of a high content of $\mathrm{N}$ present in the form of non-protein compounds. Feeding a high-energy supplement can improve the feeding value of saltbush pastures by providing ruminal microbes with energy to produce microbial protein, to stimulate carbohydrate digestion and to detoxify secondary metabolites (Norman et al., 2008). On the contrary, when the two plants were mixed together, the concentration of the secondary metabolites increased over the ability of ruminal microflora to tolerate, causing the observed negative effects.

The dressing percentage was almost the same for TC30 and the control. However, AT15 and AC15 lowered the dressing percentage compared to the control. Al-Owaimer et al. (2008) noted that dressing percentage was greater in lambs fed a diet without AT than those fed a diet with AT. However, Abdul Aziz et al. (2001) found that dressing percentage increased in lambs fed AC compared to those fed the control diet. No differences were observed in the physical characteristics of the 9-11th ribs. However, lambs fed AT15 had an increased weight over the other lambs.

With the exception of $\mathrm{CP}$ content, the chemical composition of the 9-11th ribs was not affected. The total fat contents of the carcass increased with the experimental diets versus the control. However, a number of studies have concluded that consuming saltbush or a diet high in salt may decrease carcass fat content and increase the lean proportion compared to animals grazing either a grain-hay-based diet or a pasture-stubble paddock (Kraidees et al., 1998; Pearce et al., 2010). Al-Owaimer et al. (2008) found that lambs fed a complete diet containing AT had a lower fat content than those fed the control diet. The increase in carcass fat contents in our study might be due to the synergism of the two plants supplemented and/or some kind of complementary effects between the high content of grains and molasses in the diet.

\subsection{Intestinal histopathology}

The microscopic examination showed that the ileum of lambs fed either AT or AC was not degenerative and had less or no inflammatory reactions. This observation indicated that the ileum had an active absorptive function (Tufarelli et al., 2010). Excess goblet cells formed in these lambs suggested an active mucus secretory function.

The main and common alterations observed under microscopic examination with the experimental diets were the shortness in the height of the ileal villi. The shorter villi were somewhat thickened owing to congestion and dilatation of the lacteal vessels while the epithelium was active and contained excess goblet cells with less or no vacuolation or microvesicular formation. In this respect, Robins and Brooker (2005) stated a marked increase in villous height and crypt depth were recorded for abomasal and intestinal samples of sheep fed Acacia aneura compared 
with polyethylene glycol as a control. Long and thin gastric pits adjacent to the surface were a feature of $A$. aneura-fed sheep, contrasting with deep and wide gastric pits open to the luminal surface in sheep fed hay chaff. Abomasal epithelia of sheep fed with $A$. aneura and $A$. aneura plus polyethylene glycol showed discrete areas of tissue fragility compared with sheep fed hay chaff.

Generally, it is clear that feeding diets containing AT and $A C$ led to negative effects on the intestinal morphological properties in ileum which could reduce the absorptive surface in digestive tract and consequently decrease lamb growth performance.

\section{Conclusion}

It could be concluded that $A$. nummularia and $A$. saligna could replace berseem hay up to $50 \%$ in the diet of Barki lambs without compromise of lamb growth performance, although feeding $A$. nummularia and $A$. saligna led to some changes in intestinal morphological properties. Thus, the use of these plants as a feed supplement for livestock may be considered as a partial solution to the problem of feed shortage. More studies are required to evaluate effects of inclusion of these halophytic forage shrubs at different levels on small ruminant production, especially on a large scale.

\section{Conflicts of interest}

None declared.

\section{References}

Abdul Aziz, G.M., El Shaer, H.M., Fahmy, A.A., Shalaby, A.S., El Gawad, A.M., 2001. Carcass quality of fattened sheep fed halophytic silage with non-conventional energy supplements in Egypt. Options Mediterraneennes Serie A: Seminaires Mediterraneens 46, 35-39.

Abu-Zanat, M.M.W., 2005. Voluntary intake and digestibility of saltbush by sheep. Asian Australas. J. Anim. Sci. 18, 214-220.

Abu-Zanat, M.M.W., Tabbaa, M.J., 2006. Effect of feeding Atriplex browse to lactating ewes on milk yield and growth rate of their lambs. Small Rumin. Res. 64, 152-161.

Al-Owaimer, A.N., Zahran, S.M., Al-Basam, B.A., 2008. Effect of feeding some types of Atriplex SPP. in complete diet on growth performance and digestibility of growing lambs. Agric. Res. Bull. No King Saud Univ. Riyadh, Saudi Arabia 161, 5-19.

Alsersy, H., Salem, A.Z.M., Borhami, B.E., Olivares, J., Gado, H.M., Mariezcurrena, M.D., Yacuot, M.H., Kholif, A.E., El-Adawy, M., Hernandez, S.R., 2015. Effect of Mediterranean saltbush (Atriplex halimus) ensilaging with two developed enzyme cocktails on feed intake, nutrient digestibility and ruminal fermentation in sheep. Anim. Sci. J. 86, 51-58.

AOAC, 1997. Association of Official Analytical Chemists. Official Methods of Analysis, 16th ed. AOAC, Arlington, VA, USA.

Arieli, A., Naim, E., Benjamin, R.W., Pasternak, D., 1989. The effect of feeding saltbush and sodium chloride on energy metabolism in sheep. Anim. Prod. 49, 51-57.

Bhatti, R., (PhD thesis) 2009. Evaluation on of saltbush (Atriplex amnicola) in Kajli lambs as a substitute of Lucerne hay based total mixed ration. Faculty of Animal Husbandry University of Agriculture, Faisalabad, Pakistan.

Barry, T.N., 1985. The role of condensed tannins in the nutritional value of Lotus pedunnculatus for sheep. 3. Rates of body and wool growth. Br. J. Nutr. 54, 211-217.

Ben Salem, H., Norman, H.C., Nefzaoui, A., Mayberry, D.E., Pearce, K.L., Revell, D.K., 2010. Potential use of oldman saltbush (Atriplex nummularia Lindl.) in sheep and goat feeding. Small Rumin. Res. 91, 13-28.

Bravo, L., Manas, E., Calixto, F.S., 1993. Dietary non extractable condensed tannins as indigestible compound: effect on fecal weight and protein and fat excretion. J. Sci. Food Agric. 63, 63-68.
Cenci, F.B., Louvandini, H., Mcmanus, A., Dell'porto, C.M., Costa, D.M., Araujo, S.C., Minho, A.P., Abdalla, A.L., 2006. Effects of condensed tannin from Acacia mearnsii on sheep infected naturally with gastrointestinal helminthes. Vet. Parasitol. 24, 12-22.

Culling, C.F., 1983. Handbook of Histopathological and Histochemica Techniqes, 3rd ed. Butterworth, London.

Degan, A.A., Blankc, A., Beker, K., Kam, M., Benjamin, R.W., Makkar, H.P.S., 1997. The nutritive value of Acacia saligna and Acacia saligna for goats and sheep. J. Anim. Sci. 64, 253-259.

Du Toit, C.J.L., Van Niekerk, W.A., Abubeker, H., Rethman, N.F.G., Coertze, R.J., 2006. Fermentation in the rumen of sheep fed Atriplex nummularia cv. De Kock supplemented with incremental levels of barley and maize grain. South Afr. J. Anim. Sci. 36, 74-77.

FASS, 1999. Guide for the Care and Use of Agricultural Animals in Agricultural Research and Teaching. Fed. Anim. Sci. Soc., Champaign, IL.

Fayed, A.M., El-Essawy, A.M., Eid, E.Y., Helal, H.G., Abdou, A.R., El Shaer, H.M., 2010. Utilization of berseem and Atriplex for feeding sheep under saline conditions of South Sinai, Egypt. J. Am. Sci. 6, 1447-1461.

Garcia, J., Carabaño, R., De Blas, J.C., 1999. Effect of fibre source on cell wall digestibility and rate of passage in rabbits. J. Anim. Sci. 77, 898-905.

Gips, G.H., Wibbens-Alberts, M., 1968. Ammonia determination in blood using the TCA direct method. Clin. Chim. Acta 22, 183.

Heuzé, V., Tran, G., Bastianelli, D., Boudon, A., Lebas, F., 2014. Berseem (Trifolium alexandrinum). Feedipedia.org. A Programme by INRA, CIRAD, AFZ and FAO. http://www.feedipedia.org/node/248

Kaneko, J.J., 1989. Clinical Biochemistry of Domestic Animals, 4th ed. Academic Press.

Khalil, J.K., Sawaya, W.N., Hyder, S.Z., 1986. Nutrient composition of Atriplex leaves grown in Saudi Arabia. J. Range Manage. 39, 104-107.

Kholif, A.E., Khattab, H.M., El-Shewy, A.A., Salem, A.Z.M., Kholif, A.M., El-Sayed, M.M., Gado, H.M., Mariezcurrena, M.D., 2014. Nutrient digestibility, ruminal fermentation activities, serum parameters and milk production and composition of lactating goats fed diets containing rice straw treated with Pleurotus ostreatus. Asian Australas. J. Anim. Sci. 27, 357-364

Kraidees, M.S., Abouheif, M.A., Al-Saiady, M.Y., Tag-Eldin, A., Metwally, H., 1998. The effect of dietary inclusion of halophyte Salicornia bigelovii Torr on growth performance and carcass characteristics of lambs. Anim. Feed Sci. Technol. 76, 149-159.

Kumar, N.U., Singh, B., Verma, D.N., 1980. Effect of different levels of dietary protein and energy on growth of male buffalo calves. Ind. J. Anim. Sci. 51, 513

Le Houérou, H.N., 1992. The role of saltbushes (Atriplex spp.) in arid land rehabilitation in the Mediterranean Basin: a review. Agrofor. Syst. 18, 107-148.

Masters, D.G., Rintoul, A.J., Dynes, R.A., Pearce, K.L., Norman, H.C., 2005. Feed intake and production in sheep fed diets high in sodium and potassium. Aust. J. Agric. Res. 56, 427-434.

Morehouse, L.A., Bangerter, F.W., Deninno, M.P., Inskeep, P.B., Mccarthy, P.A., Pettini, J.L., Savoy, Y.E., Sugarman, E.D., Wilkims, R.W., Wilson, T.C., Woody, H.A., Zaccaro, L.M., Chandler, C.E., 1999. Comparison of synthetic saponin cholesterol absorption inhibitors in rabbits: evidence for non-stoichiometric, intestinal mechanisms of action. J. Lip. Res. 40, 464-474.

Moujahed, N., Salem, H.B., Kayouli, C., 2005. Effects of frequency of polyethylene glycol and protein supplementation on intake and digestion of Acacia cyanophylla Lindl. Foliage fed to sheep and goats. Small Rumin. Res. 56, 65-73.

Newbold, J.R., Baughan, J., Davies, D.R., Theodorouu, M.K., 1996. Use of automated pressure evaluation system to measure the performance the fermentable energy content of ruminant feedstuffs: additivity of estimates. Irish Soc. Anim. Sci., 221

Norman, H.C., Masters, D.G., Wilmot, M.G., Rintoul, A., 2008. Effect of supplementation with grain, hay or straw on the performance of weaner Merino sheep grazing old man (Atriplex nummularia) or river (Atriplex amnicola) saltbush. Grass Forage Sci. 63, 179-192.

NRC, 1985. Nutrient Requirements of Sheep, 6th revised ed. National Academy Press, Washington, DC, USA

Pearce, K.L., Normanb, H.C., Hopkins, D.L., 2010. The role of saltbush-based pasture systems for the production of high quality sheep and goat meat. Small Rumin. Res. 91, 29-38.

Robins, C., Brooker, J.D., 2005. The effects of Acacia aneura feeding on abomasal and intestinal structure and function in sheep. Anim. Feed Sci. Technol. 121, 205-215.

Romero, M.J., Madrid, J., Hernandez, F., Ceron, J.J., 2000. Digestibility and voluntary intake of vine leaves (Vitis vinifera $L$.) by sheep. Small Rumin. Res. 38, 191-195.

Salem, A.Z.M., 2005. Impact of season of harvest on in vitro gas production and dry matter degradability of Acacia saligna leaves with 
inoculation from three ruminant species. Anim. Feed Sci. Technol. 123, 67-79.

Salem, A.Z.M., Alsersy, H., Camacho, L.M., El-Adawy, M.M., Elghandour, M.M.Y., Kholif, A.E., Rivero, N., Alonso, M.U., Zaragoza, A., 2015. Feed intake, nutrient digestibility, nitrogen utilization, and ruminal fermentation activities in sheep fed Atriplex halimus ensiled with three developed enzyme cocktails. Czech J. Anim. Sci. 60, 185-194.

Salem, A.Z.M., Hassan, A.A., Khalil, M.S., Gado, H.M., Alsersy, H., Simbaya, J., 2012. Effects of sun-drying and exogenous enzymes on nutrients intake, digestibility and nitrogen utilization in sheep fed Atriplex halimus foliages. Anim. Feed Sci. Technol. 171, $128-135$.

Salem, A.Z.M., Salem, M.Z.M., El-Adawy, M.M., Robinson, P.H., 2006. Nutritive evaluations of some browse tree foliages during the dry season: secondary compounds, feed intake and in vivo digestibility in sheep and goats. Anim. Feed Sci. Technol. 127, 251-267.
Salem, A.Z.M., Kholif, A.E., Elghandour, M.M.Y., Buendía, G., Mariezcurrena, M.D., Hernandez, S.R., Camacho, L.M., 2014. Influence of oral administration of Salix babylonica extract on milk production and composition in dairy cows. Ital. J. Anim. Sci. 13, 10-14.

SAS, 2002. SAS User's Guide: Statistics. Ver 9.0. SAS Institute, Cary, NC, USA, pp. 956.

Shaker, Y.M., 2014. Live body weight changes and physiological performance of Barki sheep fed salt tolerant fodder crops under the arid conditions of southern Sinai, Egypt. J. Am. Sci. 10, 78-88.

Tufarelli, V., Desantis, S., Zizza, S., Laudadio, V., 2010. Performance, gut morphology and carcass characteristics of fattening rabbits as affected by particle size of pelleted diets. Arch. Anim. Nutr. 64 (5), 373-382.

Van Soest, P.J., Robertson, J.B., Lewis, B.A., 1991. Methods for dietary fibre, neutral detergent fibre, and non-starch carbohydrates in relation to animal nutrition. J. Dairy Sci. 74, 3583-3597.

Warner, A.C.J., 1964. Production of volatile fatty acids in the rumen. Methods of measurements. Nutr. Abst. Rev. 34, 339-352. 